\title{
THE EFFECT OF GROWTH OPPORTUNITY, FIRM SIZE, AND DEBT POLICY ON FIRM VALUE MEDIATED BY PROFITABILITY IN REAL ESTATE AND PROPERTY SECTOR COMPANIES ON THE INDONESIA STOCK EXCHANGE
}

\author{
Janitra Putu Vito Veda*, Sedana Ida Bagus Panji \\ Faculty of Economics and Business, University of Udayana, Bali, Indonesia \\ *E-mail: vedjantr@gmail.com
}

\begin{abstract}
The purpose of this study is to obtain empirical evidence regarding the effect of Growth Opportunity, Firm Size, and Debt Policy on Firm Value, and examine the role of Profitability in mediating the effect of Growth Opportunity, Firm Size, and Debt Policy on Firm Value. The sampling technique used was purposive sampling method. The data used in this study is secondary data obtained from the financial statements of property and real estate companies listed on the Indonesia Stock Exchange for four years, 2016 to 2019.The data analysis technique uses path analysis techniques. The results of this study indicate that Growth Opportunity, Firm Size, and Debt Policy have a positive and significant effect on Firm Value; Profitability is able to mediate the relationship between Growth Opportunity, Firm Size, and Debt Policy to Firm Value. The implications that can be given from the research findings are that it can enrich the research model and support other empirical studies related to the effect of Growth Opportunity, Firm Size, and Debt Policy on Firm Value and the role of Profitability in mediating the effect of Growth Opportunity, Firm Size, and Debt Policy on Firm Value.
\end{abstract}

\section{KEY WORDS}

Profitability, growth opportunity, firm size, debt policy, firm value.

Maximizing the value of the company is the goal of a company. Investors in investing use the value of the company as one of the benchmarks. Firm value can be observed as the company's efforts to increase shareholder value and the company's ability to generate high profits from the funds invested by investors (Sualehkhattak, 2017). The value of the company is an important consideration for every investor because if the company is able to maintain a high company value, then the survival of the company will be guaranteed and the welfare of shareholders will be achieved (Liestyasih 2017). Therefore, company managers develop strategies in order to be able to maximize the value of the company. According to Listihayana (2020), company value is an effort to maximize the company's goals by increasing the prosperity of shareholders. An increase in company value is usually marked by an increase in the company's stock price (Deli and Kurnia, 2017).Optimizing the value of the company has an important meaning for the company, because a high company value means that the prosperity of shareholders will also be maximum, the higher the value of the company reflects the more prosperous the shareholders (Rahayu, 2019).

Every company owner will always show potential investors that their company is the right investment alternative, So if the owner of the company is not able to display a good signal about the value of the company, the value of the company will be above or below the actual value (Rohaeni, 2018).Companies use activities that provide signals to shape the expectations of investors and shareholders to want to invest in the company (Hoenig and Henkel, 2015). One of the purposes of the signaling is to provide an overview that the company has good future prospects (Connelly et al, 2011).According to signaling theory, the information contained in the company's financial statements is one of the signals issued by the company to investors, to show that the company's value is high, and is better than its competitors in the market with the aim of attracting investment and improving the company's reputation (Dang, 2019).Firm value is the existing benefits and potential benefits that can be obtained or created by the company, where these benefits are expressed in the form of values that can be measured and determined through various methods (Dang, 
2019).Through the information obtained in the company's financial statements, one way that can be used to measure the value of the company is the Tobin's $Q$ ratio (Liestyasih, 2017).One of the components used in calculating the company's Tobin's $Q$ value is the market capitalization value, where Dang (2019) states that the market capitalization value is what determines the company's current value. According to Smithers and Wright (2000) the Tobin's $Q$ ratio has an advantage because in addition to reflecting the company's assets as a whole and reflecting market sentiment (analysis seen from the company's prospects or speculation), this ratio can also reflect the company's intellectual capital. Tobin's $Q$ ratio is considered the best predictor of market correction (Sucuahi and Cambarihan, 2016).Sucuahi and Cambarihan (2016) added, this ratio can also be used in a company's financial analysis where investors who will buy shares of a company will measure the company's Tobin's $Q$ ratio. This ratio describes the effectiveness of management in utilizing its resources. The firm value reflected by the Tobin's $Q$ ratio is influenced by several factors, such as growth opportunity (Pangulu, 2015), firm size (Valentina, 2020), debt policy (Titin, 2013), and company profitability (Sucuahi and Cambarihan, 2016).

Growth opportunity is the company's opportunity to grow and invest in things that benefit the company (Listihayana, 2020). The company's growth is highly expected by investors and company management, because high company growth indicates good company development (Liestyasih, 2017). Companies that grow quickly get positive results in terms of strengthening their position in the era of competition, enjoyed a significant increase in sales and was accompanied by an increase in market share and as an illustration the company was able to develop its business with its internal capabilities (Burhanuddin and Dicky, 2019). A company that will experience high growth in the future will tend to require new capital to finance its growth (Brigham and Gapensky, 1996). This high growth is a signal given by the company to investors that there are good prospects from profitable companies, and they hope to benefit from their investment in the company (Suwardika, 2017).Research on growth opportunity conducted by Listihayana (2020) found that growth opportunity did not have a significant effect on firm value, while the research conducted by Gharaibeh (2017) obtained results where growth opportunity had a significant positive effect on firm value. The benchmark used in measuring growth opportunity in this study is sales growth (Listihayana, 2020).

Firm size is a scale where the size of a company can be measured by the total assets owned by the company (Kopong, 2016).In general, large companies are better known by the public and easier to provide information which is a signal because of the large number of investors (Dewi, 2019). Investors trust large companies more than small ones because large companies are considered to have more stable conditions, making it easier for companies to raise capital. Sari and Priyadi (2016) in their research stated that large companies have greater access and ease of obtaining funding from various sources. Because large companies have more resources, they are easier to achieve their goals (Mule, 2015).This convenience is a favorable signal for investors in making investment decisions and will affect the value of the company in the future (Nurhayati, 2013). The larger the size of the company will affect management decisions in managing the funds used, sourced from external and internal sources, in order to be able to achieve a high level of profit and optimize the value of the company. Research on firm size conducted by Dang (2019) found results where firm size had a negative and significant impact on firm value, while research conducted by Aggarwal (2017) and Bandanuji (2020) obtained results where firm size has a positive effect on firm value. Firm size in this study was measured using the natural logarithm of the company's total assets (Kariuki et al., 2015).

Debt policy is a policy taken by management in order to obtain sources of financing for the company so that it can be used to finance the company's operational activities (Sukmawardini, 2018).Debt policy includes company funding policies that are sourced from external companies (Zumrotun and Sopi, 2020).Debt management is very important because the high use of debt can increase the value of the company due to tax protection (Setiadewi, 2015).This is in accordance with the theory developed by Modigliani and Miller, where the theory states that the value of a company with debt will be higher than the value of a 
company without debt (Setiawati, 2016).On the other hand, according to Vivi (2019) stating that the use of debt is in accordance with signaling theory because the use of more debt can be a more reliable signal by the company to investors. There are differences in the findings of the two studies; this study will try to contribute to the differences in these findings in looking at the relationship between debt policy and firm value. Ross (1977) in his research states that managers have information that investors do not have, so that managers can send clear signals about the company's future by using debt, thus increasing the value of the company. This is because companies that dare to increase the use of debt are seen as companies that are confident in the company's future prospects (Darmanto and Ardiansari, 2017). Mardiyati (2012) stated that the higher the portion of debt used, the higher the company's stock price. In this study, debt policy is measured using the Debt to Equity Ratio or DER (Gregorius and Dominicus, 2017).Good debt management reflects the efforts to achieve the success of a company in its operating activities. If the company generates higher income from the use of its debt, then the debt has a good influence on the company. On the other hand, if the company's income cannot cover its obligations, it will have a bad effect on the company (Frans and Achmad, 2020). Research on debt policy conducted by Zumrotun and Sofi (2020) found results where debt policy had no effect on firm value, research by Gregory (2017) obtained results where debt policy had a negative and significant impact on firm value, while the research conducted by Sualehkhattak (2017) obtained results where debt policy had a positive effect on firm value.

A lot of research has been done on the value of the company and the results found are different. Inconsistent results from studies regarding the effect of growth opportunity, firm size, and debt policy into a research gap is the reason for conducting this research by adding profitability as a mediating variable. Yoo (2015) states that growth-oriented companies will focus on innovations that will increase the company's growth rate in the long term., so that it will not only increase the company's profitability, but also the company's survival in the future. Companies with large sizes are able to carry out production levels at low costs, so that the size of the company is one of the factors that determine the level of company profitability (Niresh, 2014). The use of debt will make the company's management to work hard in order to be able to increase the company's profitability so that the company can meet the obligations of the use of the debt (Lumapow, 2020). Profitability is an important indicator and is a component in creating a company's value while ensuring good company prospects in the long term (Pamungkas and Achmad, 2017).Profitability is expected to mediate the effect of growth opportunity, firm size, and debt policy on firm value because there is a positive effect between growth opportunity, firm size, and debt policy with profitability and firm value. This is supported by the results of research conducted by Widiyanto (2018), Astutiningrum (2017), Laksitaputri (2012), and Dewi (2019).Profitability is thought to be another variable that also influences the relationship between growth opportunity, firm size, and debt policy variables with firm value being an indirect relationship. Based on this empirical study, this study tries to find out how profitability mediates between growth opportunity, firm size, and debt policy with firm value.

According to Nimalathasan and Subramaniyam (2009), profit is the main goal in a business, from the point of view where investment is the key to the company's success. Profit from the accounting side tends to be a long-term goal for companies that not only measure the success of their products, but also market development for these products (Nishantini, 2013).A company must make a profit in order to be able to grow and survive in the long term. This provides an overview of the level of profit that will be obtained by the company in the future and how effectively the company is managed. If the company fails to make a profit, the invested capital will be lost, and the company will be threatened with bankruptcy if this situation continues.

Profit and profitability are two different things. Profitability comes from 2 words, namely profit and ability. Nimalathasan (2009) defines profit as "excess of return over outlay" or the rate of return received for the costs incurred. Profit has different meanings depending on its use and the company's goals in achieving profit. Therefore, profitability is the company's ability to provide a return on the investment used. 
Profitability is one of the factors supporting the value of the company which is a work achievement that has been achieved by the company in a certain period and is stated in the financial statements of the company concerned (Christiani, 2019).Profitability can provide useful clues in assessing the effectiveness of a company's operations, so that the profitability ratio will show a combination of the effects of liquidity, asset management, and debt on operating results (Khafa and Laksito, 2015). The company's profitability can be seen from the company's profitability ratio (Zuhroh, 2019).Profitability ratio is a ratio that measures management effectiveness, based on the returns that can be generated through sales and investments (Westonand Copeland, 2010:237). The value of a high profitability ratio means that the company is able to generate profits from sources that are used efficiently, so as to increase the value of the company. Return on Assets or ROA is one of the profitability ratios that can be used as a measure of company profitability (Kamaliah, 2020). Research conducted by Kristianus (2020 and Dang (2019) which examined the effect of profitability on firm value obtained results where profitability had a positive and significant effect on firm value.Vivi (2019) and Titin (2013) in their research obtained results where profitability does not have a significant effect on firm value.

In accordance with signaling theory, companies with a high level of profitability will try to provide information to investors that the company has been able to run its business well (Vivi, 2019).The high profitability shows a good company perspective and investors want to react positively so that the value of the company increases (Sujoko and Soebintaro, 2007). High profitability indicates high efficiency in managing the resources owned in creating these profits (Rahayu, 2019). Yazdanfar (2013) in his research states that in addition to significantly influencing the achievement of other company financial goals, the importance of the company's profitability level also has an impact on economic growth, job vacancies, innovation, and technological change.

Growth opportunity will affect the profitability of the company, through the assets owned so that it affects the productivity and efficiency of the company which in turn affects profitability (Rosnani and Henni, 2020).Companies that have a high growth opportunity have a large investment value, especially in fixed assets with an economic life of more than one year. The impact of this large investment is that companies that have high growth opportunities will obtain high profitability (Setiawan, 2009). Research on the growth opportunity variable on profitability conducted by Setiadewi (2015) obtained results where growth opportunity had an insignificant effect on profitability, while the research conducted by Clara (2015) and Fuertes-Callen and Cuellar-Fernandez (2019) obtained results where growth opportunity had a positive and significant effect on company profitability.

Firm size will affect the company's profitability because large companies will need large funds to maintain the continuity of their operations and obtain a level of profit from the investments invested. The size of a company is the main factor in determining the company's profitability according to the concept of economies of scale that can be found in the neoclassical view of the company (Niresh, 2014). Large companies with large economies of scale also have the ability to negotiate prices and make purchases in large quantities which will have an impact on total sales and profitability (Azhar, 2019). The high level of profitability generated by the company can maintain the value of the company, because it will help investors feel safe in investing their funds in the company, so it will be able to increase the value of the company. Research conducted by Gharaibeh (2017) and Azhar (2019) obtained results where firm size has no effect on company profitability. Different results were obtained by Pradnyanita (2019) where firm size had a negative and significant effect on profitability, and Robi (2016) where firm size had a positive and significant effect on profitability.

Debt policy can affect the company's profitability. Signaling theory shows a behavior of company management in providing investor information regarding the company's views and prospects for the future (Brigham and Houston, 2010: 184). Based on this theory, companies that use debt to fund their operations can be seen as a signal by investors that companies will use debt to grow or expand (Septiani, 2018). The use of large debt that is not accompanied by good management will increase the interest expense borne by the company, so that it can reduce the company's profitability (Nurhasanah, 2012). Research on 
debt policy variables on profitability conducted by Yudha (2013), Kartikasari (2016), and Zuhroh (2019) obtained results where debt policy had a positive and significant effect on company profitability, Yaslim (2020) obtained results where debt policy had a negative and significant effect on company profitability.

The company's ability to adapt and continue to grow when faced with difficult situations will show management's consistency in achieving company goals. For this reason, a study was conducted on the real estate and property industry which experienced growth in 20172018.

The growth in the 2017-2018 period is a momentum for the growth of the property sector. Several things that encourage this growth are, first, the government's policy of loosening property loans / LTV (Loan to Value), As a result, the banking industry has the authority to regulate the amount of property credit / LTV. The loosening of the LTV ratio could push back the people's purchasing power for property. This has further strengthened the opportunities for the property sector in 2019. Especially with the tightening economic conditions, where BI still maintains its benchmark interest rate at $6.0 \%$.Second, the recovery in the property sector was also boosted by the reduction of PPh22 \& PPnBM taxes. The reason is that the two taxes will be abolished, but in the end the government actually changes the threshold / lower limit for luxury house prices that will be subject to PPnBM. Third, the property sector also gets a boost from the infrastructure sector. Where infrastructure development in recent years is very massive. The reason is that infrastructure development is one of the keys to the property industry cycle. Considering that currently many properties have been built by offering various strategic access facilities. Of course it is a result of infrastructure development.

The following is information on the movement of the company value of the 10 largest property companies listed on the Indonesia Stock Exchange as measured by Tobin's Q, during the 2016-2019 period:

Table 1 - Data of Tobin's Q Real Estate and Property Companies 2016-2019

\begin{tabular}{lllllll}
\hline No & Stock Code & Company Name & 2016 & 2017 & 2018 & 2019 \\
\hline 1 & LPKR & Lippo KarawaciTbk. & $93,49 \%$ & $67,24 \%$ & $54,83 \%$ & $68,74 \%$ \\
\hline 2 & BSDE & Bumi Serpong Damai Tbk. & $124,17 \%$ & $107,67 \%$ & $84,43 \%$ & $82,75 \%$ \\
\hline 3 & CTRA & Ciputra Development Tbk. & $121,65 \%$ & $120,64 \%$ & $100,54 \%$ & $104,26 \%$ \\
\hline 4 & APLN & Agung Podomoro Land Tbk. & $77,97 \%$ & $74,19 \%$ & $69,24 \%$ & $68,06 \%$ \\
\hline 5 & PWON & Pakuwon Jati Tbk. & $178,31 \%$ & $186,46 \%$ & $151,62 \%$ & $135,85 \%$ \\
\hline 6 & SMRA & Summarecon Agung Tbk. & $152,62 \%$ & $124,38 \%$ & 105,77 & $120,65 \%$ \\
\hline 7 & ASRI & Alam Sutera Realty Tbk. & $98,66 \%$ & $92,39 \%$ & $79.79 \%$ & $73,12 \%$ \\
\hline 8 & PPRO & PP PropertiTbk. & $282,03 \%$ & $153,00 \%$ & $91,26 \%$ & $90,14 \%$ \\
\hline 9 & BKSL & Sentul City Tbk. & $64,94 \%$ & $76,00 \%$ & $67,46 \%$ & $65,27 \%$ \\
\hline 10 & MDLN & Modernland Realty Tbk. & $84,12 \%$ & $76,76 \%$ & $69,64 \%$ & $71,67 \%$ \\
\hline
\end{tabular}

Source: www.idx.co.id.

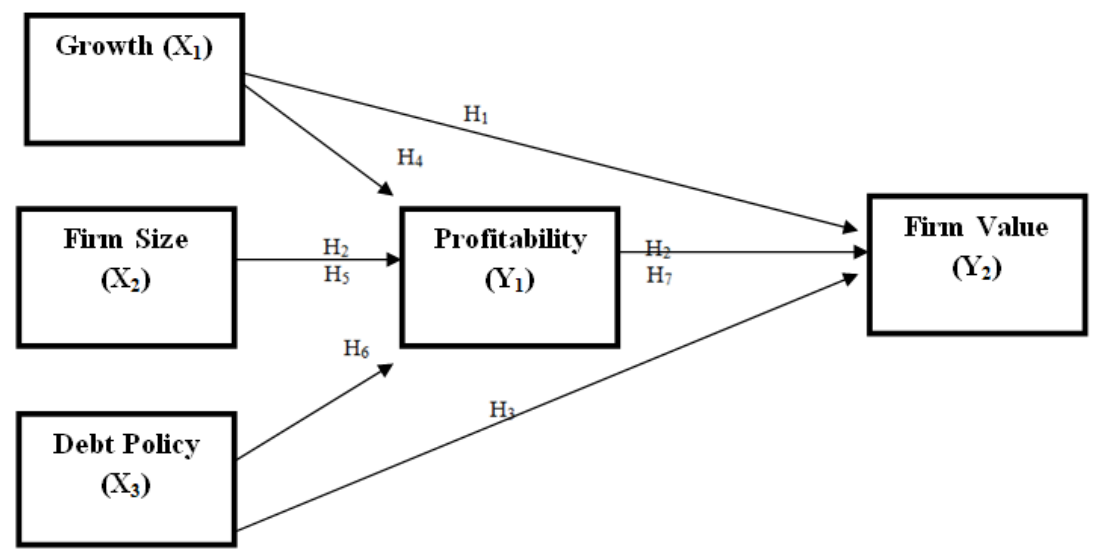

Figure 1 - Research Conceptual Framework 
Based on the table above, it can be seen that the movement in the value of Tobin's $Q$ 10 largest property companies in 2019 tends to decline. The different conditions of the prospect and the movement in the value of Tobin's $Q$ which tends to decline are interesting to study, because the role of investors here is very influential in their investment in a company, especially companies in the property industry. This study uses firm value as the dependent variable to examine whether this variable is effected by growth opportunity, firm size, debt policy, with profitability as a mediating variable in property sector companies on the IDX.

Based on this background, the hypotheses in this study are:

- $\mathrm{H}_{1}$ : Growth Opportunity have a positive effect on firm value;

- $\mathrm{H}_{2}$ : Firm Size have a positive effect on firm value;

- $\mathrm{H}_{3}$ : Debt policy have a positive effect on firm value;

- $\mathrm{H}_{4}$ : Growth opportunity have a positive effect on profitability;

- $\mathrm{H}_{5}$ : Firm Size have a positive effect on profitability;

- $\mathrm{H}_{6}$ : Debt policy have a positive effect on profitability;

- $\mathrm{H}_{7}$ : Profitability have a positive effect on firm value;

- $\mathrm{H}_{8}$ : Profitability plays a role in mediating the effect of Growth Opportunity on firm value;

- $\mathrm{H}_{9}$ : Profitability plays a role in mediating the effect of Firm Size on firm value;

- $\mathrm{H}_{10}$ : Profitability plays a role in mediating the effect of debt policy on firm value.

\section{METHODS OF RESEARCH}

The theory that underlies this research is the signaling theory and the theory of Modigliani and Miller. This study uses a quantitative approach in the form of associative. The scope of this research area is the property sector companies listed on the Indonesia Stock Exchange in 2016-2019, by accessing the website www.idx.co.id.The secondary data in this study is the annual report of property companies listed on the IDX for the 2016-2019 period, which was obtained through the IDX's official website. The total number of property sector companies listed on the IDX is 65 companies (https://pintarsaham.id/). The sample criteria used in this study are property sector companies that have positive sales growth during the study period with details in Table 4.1.The data analysis technique in this study used path and Sobel analysis.

Table 2 - Sample Criteria

\begin{tabular}{llc}
\hline No & Sample Criteria & Total \\
\hline 1. & $\begin{array}{l}\text { The number of property and real estate companies on the IDX that publish financial reports for the } \\
2016-2019 \text { period }\end{array}$ & 43 \\
\hline & $\begin{array}{l}\text { Property and real estate companies that experienced profits during the 2016-2019 research period. } \\
\text { This criteria is chosen because high level of profitability correlates with high level of firm value } \\
\text { (Varaiya et al, 1987) }\end{array}$ & $(12)$ \\
\hline Total Sample & 31 \\
\hline
\end{tabular}

\section{RESULTS AND DISCUSSION}

The growth opportunity variable (X1) which is proxied by sales growth, has the lowest (minimum) value during the observation period, which is $-91.23 \%$ owned by PT. Fortune Mate Indonesia Tbk (FMII) in 2017, and the company's highest growth opportunity (maximum) during the observation period is $155.76 \%$ owned by PT. Puradelta Lestari Tbk (DMAS) in 2019 and has an average count (mean) of 3.62\%. This means that the average growth opportunity of property and real estate companies on the Indonesia Stock Exchange during the $2016-2019$ period is $3.62 \%$. 
Firm size variable (X2) which is proxied by the natural logarithm of total assets, has the lowest (minimum) value during the observation period, namely 25.69 owned by PT. Bekasi Asri Pemula Tbk (BAPA) in 2019, and the highest value (maximum) during the observation period is 31.63 owned by PT. Bumi Serpong Damai Tbk (BSDE) in 2019 and has an average count (mean) of 29.4174.

Table 3 - Results of Descriptive Analysis

\begin{tabular}{llllll}
\hline & Growth $(\mathrm{X} 1)$ & Size $(\mathrm{X} 2)$ & DER $(\mathrm{X} 3)$ & ROA $(\mathrm{Y} 1)$ & Tobin's Q $(\mathrm{Y} 2)$ \\
\hline Mean & $3,63 \%$ & 29,41 & $64,59 \%$ & $5,41 \%$ & $122,94 \%$ \\
\hline Minimum & $-91,23 \%$ & 25,69 & $4,33 \%$ & $0,03 \%$ & $21,33 \%$ \\
\hline Maximum & $155,76 \%$ & 219,75 & $219,75 \%$ & $35,89 \%$ & $793,15 \%$ \\
\hline
\end{tabular}

Source: Data processed, 2021.

The debt policy variable (X3) which is proxied by the Debt to Equity Ratio (DER) has the lowest value (minimum) during the observation period, which is $4.33 \%$ owned by PT. Puradelta Lestari Tbk (DMAS) in 2018, this means that the company has a fairly small debt to equity ratio. The highest (maximum) DER value during the observation period was $219.75 \%$ owned by PTPP Properti Tbk (PPRO) in 2019.This means that the company has a fairly high debt to equity ratio. The average value of DER in property and real estate sector companies during the observation period is $64.59 \%$, this means that the average use of debt is lower than the total equity of the company.

Profitability variable (Y1) which is calculated by the ratio of ROA (Return on Assets) has the lowest value (minimum) during the observation period, which is $0.03 \%$ owned by PT. Gading Development Tbk (GAMA) in 2017. The highest (maximum) ROA value during the observation period was $35.89 \%$ owned by PT Fortune Mate Indonesia Tbk (FMII) in 2016. The average value of ROA in property and real estate sector companies during the observation period is $5.409 \%$, this shows that the overall ability of the company to generate profit after tax is $5.409 \%$.

Firm Value Variable (Y2) which is proxied by Tobin's $Q$ has the lowest value of $21.33 \%$ owned by PT. Greenwood Sejahtera Tbk (GWSA) in 2013and the highest company value is 793.15\% owned by PT. Sitara Propertindo Tbk (TARA) in 2018 and an average of $122.9 \%$.This means that property and real estate companies on the Indonesia Stock Exchange for the 2016-2019 period have high company values.

Hypothesis testing in the path coefficient model analysis is divided into two types, namely the first model test and the second model test. Path analysis hypothesis test using SPSS (Statistical Package for Social Science) program.

Table 4 - Recapitulation of Direct Effect Output (First Model)

\begin{tabular}{|c|c|c|c|c|c|c|}
\hline \multirow{2}{*}{\multicolumn{2}{|c|}{ Model }} & \multicolumn{2}{|c|}{ Unstandardized Coefficients } & \multirow{2}{*}{$\begin{array}{l}\text { Standardized Coefficients } \\
\text { Beta }\end{array}$} & \multirow[b]{2}{*}{$\mathrm{t}$} & \multirow{2}{*}{ Sig } \\
\hline & & $\mathrm{B}$ & Std. Error & & & \\
\hline \multirow{4}{*}{1} & (Constant) & $-7,823$ & 10,258 & & $-0,76$ & 0,447 \\
\hline & Growth (X1) & 0,57 & 0,014 & 0,343 & 4,102 & 0 \\
\hline & Size $(X 2)$ & 0,495 & 0,22 & 0,127 & 2,295 & 0,027 \\
\hline & $\operatorname{DER}(X 3)$ & 0,024 & 0,009 & 0,229 & 2,506 & 0,014 \\
\hline
\end{tabular}

Source: Data processed, 2021.

Table 4 shows the magnitude of the direct effect on the first model that obtained the structural model results, which are as follows:

$$
Y_{1}=0,343 X_{1}+0,127 X_{2}+0,229 X_{3}
$$

Where:

$Y_{1}=$ Profitability;

$\mathrm{X}_{1}=$ Growth Opportunity;

$\mathrm{X}_{2}=$ Firm Size;

$\mathrm{X} 3=$ Debt Policy. 
Table 5 - Recapitulation of Direct Effect Output (Second Model)

\begin{tabular}{|c|c|c|c|c|c|c|}
\hline \multirow{2}{*}{\multicolumn{2}{|c|}{ Model }} & \multicolumn{2}{|c|}{ Unstandardized Coefficients } & \multirow{2}{*}{$\begin{array}{l}\text { Standardized Coefficients } \\
\text { Beta }\end{array}$} & \multirow[b]{2}{*}{$t$} & \multirow{2}{*}{ Sig } \\
\hline & & $\mathrm{B}$ & Std. Error & & & \\
\hline \multirow{5}{*}{2} & (Constant) & 367,484 & 250,078 & & 1,469 & 0,144 \\
\hline & Growth $(X 1)$ & 0,625 & 0,262 & 0,164 & 2,387 & 0,022 \\
\hline & Size $(X 2)$ & 9,199 & 4,242 & 0,103 & 2,169 & 0,039 \\
\hline & $\operatorname{DER}(\mathrm{X} 3)$ & 0,01 & 0,005 & 0,004 & 2,094 & 0,043 \\
\hline & $\mathrm{ROA}(\mathrm{Y} 1)$ & 5,362 & 2,22 & 0,235 & 2,415 & 0,017 \\
\hline
\end{tabular}

a. Dependent Variable: Tobin's $Q(Y 2)$.

Source: Data processed, 2021

Table 5 shows the magnitude of the direct effect on the second model that obtained the structural model results, which are as follows:

$$
Y_{2}=0,164 X_{1}+0,103 X_{2}+0,004 X_{3}+0,235 Y_{1}
$$

Where:

$Y_{2}=$ Firm Value;

$Y_{1}=$ Profitability;

$\mathrm{X}_{1}=$ Growth Opportunity;

$\mathrm{X}_{2}=$ Firm Size;

X3 = Debt Policy.

Table 6 - Sobel Test Results the Role of Profitability in Mediating the Effect of Growth Opportunity on Firm Value

\begin{tabular}{lll}
\hline Effect & Z Value & P Value \\
\hline $\mathrm{X} 1>\mathrm{Y} 1>\mathrm{Y} 2$ & 2,0675 & 0,0387 \\
\hline
\end{tabular}

Source: Data processed, 2021.

Based on the results of the Sobel test above, the $Z$ value is $2.0675>1.96$ and the $P$ value is $0.0387<0.05$. So it can be concluded that profitability is able to mediate the relationship between growth opportunity and firm value.

Table 7 - Sobel Test Results the Role of Profitability in Mediating the Effect of Firm Size on Firm Value

\begin{tabular}{lll}
\hline Effect & Z Value & P Value \\
\hline $\mathrm{X} 2>\mathrm{Y} 1>\mathrm{Y} 2$ & 2,2891 & 0,025558 \\
\hline
\end{tabular}

Source: Data processed, 2021.

Based on the results of the Sobel test above, the $\mathrm{Z}$ value is $2.2891>1.96$ and the $\mathrm{P}$ value is $0.025558<0.05$.So it can be concluded that profitability is able to mediate the relationship between firm size and firm value.

Table 8 - Sobel Test Results the Role of Profitability in Mediating the Effect of Debt Policy on Firm Value

\begin{tabular}{lll}
\hline Effect & Z Value & P Value \\
\hline $\mathrm{X} 3>\mathrm{Y} 1>\mathrm{Y} 2$ & 2,2223 & 0,02216 \\
\hline
\end{tabular}

Source: Data processed, 2021.

Based on the results of the Sobel test above, the $Z$ value is $2.2223>1.96$ and the $P$ value is $0.02216<0.05$. So it can be concluded that profitability is able to mediate the relationship between debt policy and firm value.

The Effect of Growth Opportunity on Firm Value. The first hypothesis proposed states that growth opportunity have a positive and significant effect on firm value. The company's growth is highly expected by internal and external parties of the company, because with good 
growth will give a sign for the development of the company. In accordance with signaling theory, a high growth opportunity gives a signal to investors that the company will grow in the future and be able to generate high returns so that investors will be interested in investing their capital. These are investment opportunities that can affect the value of the company. The company's investment activities through the selection of projects or other policies such as the creation of new products will make investors expect to get a higher rate of return from time to time (Pangulu, 2015). In the end, this has an impact on increasing stock prices which will increase the value of the company's Tobin's $Q$, where the value of Tobin's $Q$ is an indicator of high company value.

The results of this study support the results of research conducted by Anggawulan (2016), Erma (2017), Gharaibeh (2017), and Kanani (2013) which obtained results where growth opportunity had a positive and significant effect on firm value.

The Effect of Firm Size on Firm Value. The second hypothesis proposed states that firm size has a positive and significant effect on the accepted firm value. Companies with large sizes have greater access to obtain funding from various sources, making it easier for companies to achieve their goals. Bandanuji (2020) states that the larger the size of the company, the more transparent the company is in showing its performance to outsiders. In accordance with signaling theory, this will be captured by investors as a positive signal and good company prospects in the future (Valentina, 2020).Companies with high firm size are relatively more stable and have a greater ability to generate profits, and generally are at the maturity stage and have good dividend distribution prospects in the future, so that the company will gain the trust of investors and creditors (Liestyasih, 2017). This will have an impact on increasing the value of the company's Tobin's $Q$ which ultimately reflects the high value of the company.

The results of this study support the results of research conducted by Hermuningsih (2018), Widiyanto (2018), Christiani (2019), Valentina (2020), Aggarwal (2017), Erma (2017), and Bandanuji (2020) which obtained the result that firm size had a positive and significant effect on firm value.

The Effect of Debt Policy on Firm Value. The third hypothesis proposed states that debt policy has a positive and significant effect on firm value received. Good debt management reflects the efforts to achieve the success of a company in its operating activities. If the company generates higher income from the use of its debt, then the debt has a good effect on the company. The positive effect of debt policy on firm value is in accordance with Modigliani and Miller's theory where the use of debt will be able to maximize firm value (Vivi, 2019).

The results of this study support the results of research conducted by Sutama (2018), Zuhroh (2019), Sualehkhattak (2017), Pratama (2016), and Vivi (2019) which obtained results where debt policy had a positive and significant effect on firm value.

The Effect of Growth Opportunity on Profitability. The fourth hypothesis proposed that growth opportunity have a positive and significant effect on profitability is accepted. Companies with high growth rates gain experience that can be used to reduce production costs and increase productivity, so as to obtain a high level of profitability and widen the distance between the company and its competitors (Yoo, 2015). The profit level earned by the company can be used to invest in new assets or expand, so as to provide a higher level of profitability. The investment made by the company on the assets owned and the company's efficiency will increase the company's profitability (Rosnani, 2020). The higher the growth opportunity owned by the company, the greater the rate of return on the company's equity (Anggawulan, 2016).

The results of this study support the results of research conducted by Clara (2015), Rosnani (2020), and Fuertes-Callen and Cuellar-Fernandez (2019) which obtained results where growth opportunity had a positive and significant effect on profitability.

The Effect of Firm Size on Profitability. The fifth hypothesis proposed that firm size have a positive and significant effect on profitability is accepted. Company size describes the size of a company that can be seen from the size of the total assets owned by a company. Companies with large assets will use existing resources as much as possible to generate 
profits. Good asset management will be able to provide a high level of sales so that it will affect the company's profitability. This positive relationship indicates a unidirectional relationship between company size and profitability because the size of a company can be seen from the amount of capital used from all sales made by the company (Chang, 2018).

The results of this study support the results of research conducted by Octaviany (2019), Robi (2016), Hirdinis (2019), and Surya (2012) which obtained results where Firm Size had a positive and significant effect on profitability.

The Effect of Debt Policy on Profitability. The sixth hypothesis proposed that debt policy have a positive and significant effect on profitability is accepted. In accordance with signaling theory, companies that use debt are a signal to investors that the company will grow or expand (Septiani, 2018). The use of debt that is good and managed efficiently will be able to increase the company's profitability (Kartikasari, 2016).

The results of this study support the results of research conducted by Pratama (2016), Saira (2011), Yudha (2013), and Kartikasari (2016) where debt policy had a positive and significant effect on company profitability.

The Effect of Profitability on Firm Value. The seventh hypothesis proposed states that profitability have a positive and significant effect on firm value received. Based on signaling theory, companies with a high level of profitability will try to provide information to their shareholders that the company has a good business to achieve a high level of profitability (Kristianus, 2020).A high profitability value indicates that the company's ability to earn profits also increases, so that the company's ability to distribute dividends to shareholders will also increase (Suwardika, 2017).Companies can also use the profits earned as internal funds to invest accordingly, so that the company's prospects in the future are good. This will attract investors to invest, so it will increase the value of the company.

The results of this study support the results of research conducted by Rahayu (2019), Zuhroh (2019), Valentina (2020), Kristianus (2020), Sucuahi (2016), and Gregorius (2017) which obtained results where profitability had a positive and significant effect on firm value.

The Role of Profitability in Mediating the Effect of Growth Opportunity on Firm Value. The results of this study obtained results where the growth opportunity variable on profitability was significant and the effect of profitability on firm value also showed significant results. Based on these results, it can be said that profitability is able to mediate the relationship between growth opportunity and firm value. The mediation criteria obtained from the processed data is partial mediation.

Companies with increasing sales growth every year can indicate that the company has a high growth opportunity; this will increase the level of company profitability. A high level of profitability will attract investors to invest, as well as guarantee the company's ability to distribute dividends on the profits that have been received. Companies with large growth opportunities and high profitability will be able to show good company performance, and be able to give a signal to investors to invest in the company and have an impact on increasing company value. The results of this study support the results of research conducted by Widiyanto (2018) which obtained results where profitability is able to mediate the relationship between growth opportunity and firm value.

The Role of Profitability in Mediating Firm Size on Firm Value. The results of this study obtained results where the firm size variable on profitability was significant and the effect of profitability on firm value also showed significant results. Based on these results, it can be said that profitability is able to mediate the relationship between firm size and firm value. The mediation criteria obtained from the processed data is partial mediation.

Companies with a large size have a large number of assets as well. Companies with large assets can use existing assets optimally and efficiently for company operations that aim to obtain maximum profits. Azhar (2019) states those companies with large sizes have the ability to negotiate prices and make purchases in large quantities which will have an impact on total sales and profitability. In accordance with signaling theory, the high level of profit is a signal given to the company which indicates that the company's condition is good. The high level of profitability of the company will make investors feel safe in investing their funds. This will be able to increase the value of the company. 
The results of this study support the results of research conducted by Widiyanto (2018), Dewi (2019), and Laksitaputri (2012) which obtained results where profitability was able to mediate the relationship between firm size and firm value.

The Role of Profitability in Mediating Debt Policy on Firm Value. The results of this study obtained results where the debt policy variable on profitability was significant and the effect of profitability on firm value also showed significant results. Based on these results, it can be said that profitability is able to mediate the relationship between debt policy and firm value. The mediation criteria obtained from the processed data is partial mediation.

The use of debt can be seen as a signal by investors that the company will expand. The additional funds obtained by the company in the form of debt can be used to obtain higher profits by using capital derived from debt or assets financed by debt. With this, the company can optimally run its business so that the profits obtained by the company will increase. Companies that are able to utilize debt optimally will generate profits (Hirdinis, 2019).Signaling theory states that a high level of profitability provides information to shareholders that the company has managed debt well so that it is able to make a profit. This is a signal that is reflected in the company's financial statements, so that it attracts investors to invest in the company, and will increase the value of the company. The results of this study support the results of research conducted by Widiyanto (2018), Dewi (2019), and Astutiningrum (2017) which obtained results where profitability was able to mediate the relationship between debt policy and firm value.

\section{CONCLUSION}

The results of the research and discussion in this study can be concluded as follows, namely Growth Opportunity, Firm size, debt policy, and profitability have a positive effect on Firm Value of real estate and property sector companies on the IDX for the 2016-2019 period. Growth Opportunity, firm size and debt policy have a positive effect on the profitability of real estate and property sector companies on the IDX for the 2016-2019 period. Profitability plays a role in mediating the effect of growth opportunity on the value of companies in the real estate and property sectors on the IDX for the 2016-2019 period. Profitability can be said to be able to mediate the relationship between growth opportunity and firm value, mediate the effect of firm size on firm value, and mediating the effect of debt policy on firm value with mediation criteria is partial mediation.

Based on the existing conclusions, researchers can provide the following suggestions for the company, This research is expected to be an input for company management regarding the factors that affect firm value, namely growth opportunity, firm size, debt policy, and profitability as well as being a consideration for companies in making decisions related to company value so as to create a balance between increasing company performance and shareholder prosperity. Positive profitability and able to mediate the effect of growth opportunity, firm size, and debt policy with firm value indicates that the company should pay more attention to the level of company profitability. In the future, the company should pay more attention to the level of profitability because profitability can show the achievement of the company's goals and can affect investors' views on the company which will affect the value of the company.

Investors and shareholders in deciding to invest in a company should consider the growth rate, the company's total assets, the ratio of debt to company equity and the company's profit level, because this factor significantly affects the value of the company so that later the rate of return received by investors is in accordance with the investment made in the company. Further research can also expand the research population or be carried out in other sectors of companies listed on the IDX.

\section{REFERENCES}

1. Aggarwal, D. and Padhan, P.C., 2017. Impact of capital structure on firm value: Evidence from Indian hospitality industry. Theoretical Economics Letters, 7(4), pp.982-1000. 
2. Astutiningrum, D., 2017. Pengaruh Leverage, Ukuran Perusahaan, dan Investment Opportunity Set (IOS) Terhadap Nilai Perusahaan dengan Profitabilitas sebagai Variabel Intervening (Studi Pada Perusahaan Manufaktur Terdaftar di BEI Periode 2010-2014).

3. Azhar, K.A. and Ahmed, N., 2019. Relationship between firm size and profitability: investigation from textile sector of Pakistan. International Journal of Information, Business and Management, 11(2), pp.62-73.

4. Bandanuji, A. and Khoiruddin, M., 2020. The Effect of Business Risk and Firm Size on Firm Value with Debt Policy as Intervening Variable. Management Analysis Journal, 9(2), pp. 200-210.

5. Brigham, E., \&Gapenski. (1996). Intermediate Financial Management. Dryden.

6. Brigham, E., \& Houston, J. (2010). Dasar-Dasar Manajemen Keuangan. Edisi 11. Buku 1. Jakarta: SalembaEmpat.

7. Burhanuddin, dan Yusuf, Dicky. 2019. Pengaruh Struktur Modal Dan Growth Opportunity Terhadap Nilai Perusahaan. Jurnal Sinar Manajemen. 6 (1), pp: 1-11.

8. Chang, C.C., 2018. Cash conversion cycle and corporate performance: Global evidence. International Review of Economics \& Finance, 56, pp.568-581.

9. Christiani, Lisna dan Herawaty, Vinola. 2019. Pengaruh Kepemilikan Manajerial, Komite Audit, Leverage, Profitabilitas, Dan Ukuran Perusahaan Terhadap Nilai Perusahaan Dengan Manajemen Laba Sebagai Variabel Moderasi. Seminar Nasional Cendekiawanke 5 Tahun 2019 Buku 2: "Sosial dan Humaniora“. h: 1-7.

10. Connelly, B.L., Certo, S.T., Ireland, R.D. and Reutzel, C.R., 2011. Signaling theory: A review and assessment. Journal of management, 37(1), pp.39-67.

11. Dang, H.N., Vu, V.T.T., Ngo, X.T. and Hoang, H.T.V., 2019. Study the impact of growth, firm size, capital structure, and profitability on enterprise value: Evidence of enterprises in Vietnam. Journal of Corporate Accounting \& Finance, 30(1), pp.144-160.

12. Darmanto, T. and Ardiansari, A., 2017. Peran kebijakanhutangme mediasi business risk dan firm size terhadapnilaiperusahaan. Management Analysis Journal, 6(4), pp.448-460.

13. Deli, Eka Putri Ismi Novita, dan Kurnia. 2017. "Pengaruh Struktur Modal, Profitabilitas, Growth Opportunity dan Likuiditas Terhadap Nilai Perusahaan". Jurnalllmu dan Riset Akuntansi. Vol.6 No.7. pp.1-20.

14. Dewi, V.S. and Ekadjaja, A., 2020. Pengaruh Profitabilitas, Likuiditas Dan Ukuran Perusahaan Terhadap Nilai Perusahaan Pada Perusahaan Manufaktur. Jurnal Paradigma Akuntansi, 2(1), pp.118-126.

15. Fuertes-Callen, Y. and Cuellar-Fernandez, B., 2019. Inter-relationship between firm growth and profitability in a context of economic crisis (No. ART-2019-111279).

16. Gharaibeh, A.M.O. and Qader, A.A.A.A., 2017. Factors influencing firm value as measured by the Tobin's Q: Empirical evidence from the Saudi Stock Exchange (TADAWUL). International Journal of Applied Business and Economic Research, 15(6), pp.333-358.

17. Hasanah, A. (2020). Analisis Pengaruh Manajemen Modal Kerja, Pertumbuhan Penjualan Dan Kebijakan Hutang Terhadap Profitabilitas Perusahaan. Journal of Applied Managerial Accounting, 4(2), 299-309.

18. Hermuningsih, Sri. 2012. PengaruhProfitabilitas, Size Terhadap Nilai Perusahaan DenganSruktur Modal SebagaiVariabel Intervening. Jurnal Siasat Bisnis. 16(2), 232-242.

19. Hirdinis M, 2019. Capital Structure and Firm Size on Firm Value Moderated by Profitability. International Journal of Economics \& Business Administration (IJEBA), vol. $0(1)$, pp 174-191.

20. Hoenig, D. and Henkel, J., 2015. Quality signals? The role of patents, alliances, and team experience in venture capital financing. Research Policy, 44(5), pp.1049-1064.

21. Kanani, M.A., Moradi, J. and Valipour, H., 2013. Sustainable growth and firm risk from the signaling perspective. Asian Economic and Financial Review, 3(5), p.660.

22. Kariuki, Samuel, Nduati., Namusonge, Gregory S., dan Orwa, George O. 2015. Determinants of Corporate Cash holdingss: Evidence from Private Manufacturing Firms in Kenya. International Journal of Advanced Research in Management and Social Sciences. 4 (6), h: 15-33. 
23. Kartikasari, Dwiani\&Merianti, Marisa. (2016). The effect of leverage and firm size to profitability of public manufacturing companies in Indonesia. International Journal of Economics and Financial Issues. 6. 409-413.

24. Khafa, Laksito dan Herry, Laksito. 2015. Pengaruh CSR, Ukuran Perusahaan, Leverage, dan Keputusan Investasi pada Kinerja Keuangan Perusahaan dan Nilai Perusahaan. Diponegoro Journal of Accounting. 4 (4).

25. Kopong, Yeny. 2016. Pengaruh Growth Opportunity Dan Ukuran Perusahaan Terhadap Profitabilitas Dengan Nilai Perusahaan SebagaiVariabel Moderating Pada Perusahaan Manufaktur Yang Terdaftar Di Bursa Efek Indonesia Periode 2011-2014. Jurnal Akuntansi Manajerial. 1 (1), h: 116-133.

26. Laksitaputri, Iriena Maharani. (2012). Analisis Faktor-Faktor yang Mempengaruhi Nilai Perusahaan dengan Profitabilitas sebagai Variabel Intervening (Studi Pada Perusahaan Manufaktur Yang Terdaftar Di Bursa Efek Indonesia Periode 2008-2010). Jurnal Bisnis Strategi, 21( 2), 1-17.

27. Liestyasih, L.P.E. and Wiagustini, L.P., 2017. Pengaruh firm size dan growth opportunity terhadap cash holding dan firm value. E-Jurnal Ekonomi Dan Bisnis Universitas Udayana, 6, pp.3607-3636.

28. Listihayana, Yuni., dan Astuti, Susi. 2020. Analisis Pengaruh Struktur Modal, Growth Opportunity, dan Risiko SistematisTerhadap Nilai Perusahaan. Jurnalllmiah Mahasiswa Manajemen, Bisnis, dan Akuntansi. 2 (1), h: 64-71.

29. Lumapow, L. S., \&Tumiwa, R. A. F. (2020). Working Capital and Debt Policy on Profitability of The Companies. International Journal of Accounting \& Finance in Asia Pasific (IJAFAP), 3(2), 26-36.

30. Mardiyati, U., Ahmad, G. N., \& Putri, R. (2017). Pengaruh Kebijakan Dividen, Kebijakan Hutang Dan Profitabilitas Terhadap Nilai Perusahaan Manufaktur Yang Terdaftar Di Bursa Efek Indonesia (BEI) Periode 2005-2010. JRMSI - Jurnal Riset Manajemen Sains Indonesia, 3(1), 1-17

31. Mule, R. K., Mukras, M. S., \& Nzioka, O. M. (2015). Corporate size, profitability and market value: An econometric panel analysis of listed firms in Kenya. European Scientific Journal, 11(13), 376-396.

32. Niresh, A. and Thirunavukkarasu, V., 2014. Firm size and profitability: A study of listed manufacturing firms in Sri Lanka. International journal of business and management, 9(4).

33. Nurhasanah. 2012. Pengaruh Struktur Modal terhadap Profitabilitas pada Perusahaan Manufaktur yang Terdaftar Di Bursa Efek Indonesia (BEI). Jurnalllmiah, Vol 4(3): Hal. 3139.

34. Nurhayati, M. 2013. Profitabilitas, Likuiditas, dan Ukuran Perusahaan Pengaruhnya Terhadap Kebijakan Dividen dan Nilai Perusahaan Sektor Jasa. JurnalKeuangan dan Bisnis, 5(2), 144-153.

35. Octaviany, Ayu, et al. 2019. PengaruhU kuran Perusahaan dan Leverage terhadap Nilai Perusahaan dengan Profitabilitas sebagai Variabel Intervening. Jurnal Riset Inspirasi Manajemen dan Kewirausahaan. 3 (1), 30-36.

36. Pamungkas, I. D., Ghozali, I., \& Achmad, T. (2017). The effects of the whistle blowing system on financial statements fraud: Ethical behavior as the mediators. International Journal of Civil Engineering and Technology, 8(10).

37. Pangulu, Agustina, Lastri., dan Maski, Ghozali. 2015. Pengaruh Profitabilitas, Growth Opportunity, Dan Struktur Modal Terhadap Nilai Perusahaan (Studi Pada Perusahaan Perbankan Yang Terdaftar Di Bei Periode 2011- 2013). Jurnal IImiah Mahasiswa FEB Universitas Brawijaya. 3 (1), h: 1-13.

38. Pratama, I Gusti Bagus Angga. 2016. Pengaruh Ukuran Perusahaan Dan Leverage Terhadap Nilai Perusahaan Dengan Profitabilitas Sebagai Variabel Mediasi. E-Jurnal ManajemenUnud. 5 (2), h: 1338-1367.

39. Rohaeni, N., Hidayat, S., \& Fatimah, I. 2018. Nilai Perusahaan Manufaktur Di Bursa Efek Indonesia Ditinjau Dari Perspektif Kebijakan Deviden Dan Kebijakan Hutang. JBTI: JurnalBisnis: Teori dan Implementasi, 9(2), 94-99. 
40. Ross, S.A., 1977. The determination of financial structure: the incentive signaling approach. Bell J. Econ. (spring), 23-40.

41. Sari, R. A. I., \&Maswar P. P. 2016. Pengaruh Leverage, Profitabilitas, Size, dan Growth Opportunity terhadap Nilai Perusahaan. Jurnalllmu dan Riset Manajemen. Vol 5(10):117.

42. Septiani, R., Paramita, P. D., \& Putri, M. A. (2018). The Influence of Profitability and Debt Policy to Firm Value with Dividend Policy as Intervening Variable (A Case Study Of A Manufacturing Company In Indonesia's Stock Exchanges 2012-2016). Journal Of Accounting, 4(4).

43. Setiadewi, K.A.Y. and Purbawangsa, I.B.A., 2015. Pengaruhukuranperusahaan dan leverage terhadap profitabilitas dan nilaiperusahaan (Doctoral dissertation, Udayana University).

44. Setiawan, R. (2009). Pengaruh Growth Opportunity dan Ukuran Perusahaan terhadap Profitabilitas Perusahaan Industri Manufaktur di Indonesia. JurnalEkonomi dan Bisnis Airlangga (JEBA)| Journal of Economics and Business Airlangga, 19(2).

45. Setiawati, E., Pardiyanto, P., \& Efendi, I. A. (2016). Perbedaan Faktor-Faktor Yang Mempengaruhi Nilai Perusahaan Antara Perusahaan Perbankan Dan Non Perbankan (Studi Empiris pada perusahaankeuanganperbankan dan non perbankantahun 20102014). Riset Akuntansi dan Keuangan Indonesia, 1(2), 152-161.

46. Smithers, Andrew dan Wright, Stephen. (2000). Valuing Wall Street. McGraw Hill.

47. Sualehkhattak, M. and Hussain, M.C.H., 2017. Do growth opportunities influence the relationship of capital structure, dividend policy and ownership structure with firm value: Empirical evidence of KSE. Journal of Accounting and Marketing, 6(1), pp.1-11.

48. Subramaniyam, A. and Nimalathasan, B., 2009. Measurement of operational performance Through ratio analysis: A Case study of selected listed manufacturing Companies in Sri Lanka. Journal of IPM Meerut, 6, pp.59-69.

49. Sucuahi, W. and Cambarihan, J.M., 2016. Influence of profitability to the firm value of diversified companies in the Philippines. Accounting and Finance Research, 5(2), pp.149153.

50. Sujoko., dan U, Soebiantoro (2007). Pengaruh Struktur Kepemilikan Saham, Leverage, Faktor ntern dan Faktor eksternterhadap Nilai Perusahaan. Jurnal Manajemen dan Kewirausahan. 9 (1), h: 41- 48.

51. Sukmawardini, D. and Ardiansari, A., 2018. The Influence of Institutional Ownership, Profitability, Liquidity, Dividend Policy, Debt Policy on Firm Value. Management Analysis Journal, 7(2), pp.211-222.

52. Sutama, Dedi Rossidi dan Erna Lisa. 2018. Pengaruh Leverage Dan Profitabilitas Terhadap Nilai Perusahaan. Jurnal Sains Manajemen dan Akuntansi. 9 (1).

53. Suwardika, I Nyoman Agus; Mustanda, I Ketut. 2017. Pengaruh Leverage, Ukuran Perusahaan, Pertumbuhan Perusahaan, Dan Profitabilitas Terhadap Nilai Perusahaan Pada Perusahaan Properti. E-JurnalManajemen, [S.I.], 6 (3), 1248 - 1277.

54. Varaiya, N., Kerin, R.A. and Weeks, D., 1987. The relationship between growth, profitability, and firm value. Strategic Management Journal, 8(5), pp.487-497.

55. Weston, J. Freeddan Thomas E. Copaland. 2010. Manajemen Keuangan. Jilid Dua. Edisi Revisi. Diterjemaahkanoleh Jaka Wasanadan Kibrandoko. Binarupa Aksara Publisher.

56. Yaslim, Erisanofil and Masdupi, Erni. 2020. Literature Review on the Effect of Debt Policy on Stock Returns with Profitability as a Mediation Variable in Telecommunications Companies Listed on the Indonesia Stock Exchange. Advances in Economics, Business and Management Research, volume 152. 1033-1039.

57. Yazdanfar, D. (2013). Profitability determinants among micro firms: evidence from Swedish data. International Journal of Managerial Finance, 9(2), 151-160.

58. Yoo, S. and Kim, J., 2015. The dynamic relationship between growth and profitability under long-term recession: The case of Korean construction companies. Sustainability, 7(12), pp.15982-15998.

59. Zuhroh, I., 2019. The Effects of Liquidity, Firm Size, and Profitability on the Firm Value with Mediating Leverage. KnE Social Sciences, pp.203-230. 